\title{
Efisiensi Thermal Alat Pengering Tipe Tray untuk Pengeringan Pulp Campuran Tandan Kosong Kelapa Sawit dan Pelepah Pisang
}

\author{
Ratu Aqso Has ${ }^{* 1}$, Indah Purnamasari² ${ }^{2}$ Fadarina $^{3}$ \\ 1,2,3Program Studi Teknologi Kimia Industri, Jurusan Teknik Kimia \\ Politeknik Negeri Sriwijaya, Indonesia \\ Email: 1aqsohasratu@gmail.com
}

\begin{abstract}
Abstrak
Pengeringan pulp yang dilakukan masyarakat pada industri skala rumah tangga saat ini masih secara manual (konvensional) yaitu dengan memanfaatkan energi cahaya matahari atau dijemur sehingga memakan waktu yang cukup lama. Menanggapi hal tersebut, perlu adanya suatu alat pengering yang dapat mempercepat proses pengeringan pulp. Tujuan penelitian ini adalah merancang alat pengering tipe tray untuk pengeringan pulp, menentukan kinerja dari alat pengering tipe tray ditinjau dari efisiensi thermal, dan mendapatkan pulp dari campuran tandan kosong kelapa sawit dan pelepah pisang yang memenuhi standar kadar air berdasarkan Standar Nasional Indonesia No. 6106-2006. Prototype alat pengering tipe tray memiliki ukuran $39,5 \mathrm{~cm}$ x $45 \mathrm{~cm}$ x 39 $\mathrm{cm}$, berbahan stainlees steel dengan jumlah tray 4 tingkat dan menggunakan energi panas yang dihasilkan dari strip heater dan memiliki sistem konveksi paksaan. Variasi yang dilakukan pada penelitian ini di antaranya, variasi temperatur pengeringan $60^{\circ} \mathrm{C}, 70^{\circ} \mathrm{C}$, dan $80^{\circ} \mathrm{C}$ serta variasi waktu pengeringan 30 menit, 60 menit, 90 menit, 120 menit, 150 menit, 180 menit, dan 210 menit. Efisiensi thermal tertinggi pada pengering tipe tray yang didapat yaitu pada temperatur pengeringan $60^{\circ} \mathrm{C}$ dengan waktu pengeringan 120 menit yaitu sebesar $93,485 \%$. Pulp yang dihasilkan dari pengering tipe tray telah memenuhi standar mutu kadar air berdasarkan Standar Nasional Indonesia No. 6106-2006 yaitu pada temperatur pengeringan $80^{\circ} \mathrm{C}$ dengan waktu pengeringan 150 menit pada tray 1 didapatkan kadar air 7,5\%.
\end{abstract}

Kata kunci: Efisiensi Thermal, Pelepah Pisang, Pengering Tipe Tray, Pulp, TKKS.

\section{Thermal Efficiency of Tray Dryer for Pulp Drying Mixture of Oil Palm Empty Fruit Bunches and Banana Stems}

\begin{abstract}
Pulp drying carried out by the community at the current home industry scale manually (conventionally) by utilizing solar energy or drying in the sun so that it takes quite a long time. In this case, it is necessary to have a dryer that can speed up the pulp drying process. The purpose of this study was to design a tray type tester for drying pulp, determine from a tray type dryer in terms of thermal efficiency, and obtain pulp from a mixture of oil palm blanks and banana midribs that meet the water standards of the Indonesian National Standard number 6106-2006. The prototype tray type dryer has a size of $39.5 \mathrm{~cm} \times 45 \mathrm{~cm} \times 39 \mathrm{~cm}$, made of stainless steel with a 4 level tray and uses heat energy generated from a strip heater and has a forced convection system. Variations carried out in this study include variations in drying $60^{\circ} \mathrm{C}, 70^{\circ} \mathrm{C}$, and $80^{\circ} \mathrm{C}$ as well as variations in drying time of 30 minutes, 60 minutes, 90 minutes, 120 minutes, 150 minutes, 180 minutes, and 210 minutes. The highest thermal on tray type drying is obtained at a drying temperature of $60^{\circ} \mathrm{C}$ with a drying time of 120 minutes, which is $93.485 \%$. The pulp produced from tray type drying has met the water standard based on the Indonesian National Standard No. 6106-2006, namely at a drying temperature of $80^{\circ} \mathrm{C}$ with a drying time of 150 minutes in $1^{\text {st }}$ tray, the air content is $7,5 \%$.
\end{abstract}

Keywords: Banana Stem, OPEFB, Pulp, Thermal Efficiency, Tray Dryer.

\section{PENDAHULUAN}

Pengeringan pulp merupakan salah satu tahap utama dalam menghasilkan pulp yang berkualitas baik. Pengeringan pulp dapat mempengaruhi ikatan antar serat pulp, yaitu ikatan hidrogen kekuatan pada jaringan. Jika suhu terlalu tinggi, serat-serat pada permukaan lembaran pulp akan mengering dan melekat pada permukaan pengering sehingga hasil pulp menjadi rusak [1]. 
Pengeringan pulp yang dilakukan oleh masyarakat pada industri skala rumah tangga masih bersifat konvensional hingga saat ini yaitu dengan menggunakan energi matahari atau dijemur. Cara ini memiliki banyak kekurangan seperti panas yang fluktuatif, kebersihan yang kurang terjaga, waktu pengeringan yang relatif lebih lama, kadar air produk yang tidak seragam, dan memerlukan tempat yang cukup luas [2]. Pada industri skala besar, pengeringan pulp dilakukan dengan menggunakan alat silinder dryer yang dialiri steam. Sistem pengeringan pada alat ini membutuhkan sumber energi yang cukup tinggi yaitu berkisar $30 \mathrm{kWh} / \mathrm{ADT}$ dengan temperatur steam $112^{\circ} \mathrm{C}-139^{\circ} \mathrm{C}$ [3], sehingga tidak memungkinkan untuk digunakan pada industri skala rumah tangga.

Pengering tipe tray dapat digunakan pada pengeringan bahan padatan kental maupun padatan seperti pasta, dimana bahan tersebut disebarkan secara merata pada rak-rak pengering [4]. Proses pengeringan yang menggunakan pengering tipe tray memiliki tingkat efisiensi penggunaan energi yang cukup efisien dengan laju pengeringan yang lebih cepat [5]. Sehingga, alat pengering tipe tray sangat memungkinkan untuk mengeringkan padatan seperti pulp. Berdasarkan penelitian yang dilakukan [6], telah dirancang alat pengering tipe tray untuk pengeringan silika gel berbasis ampas tebu, dengan laju pengeringan yang didapat sebesar 0,01941 kg/jam.m² dan efisiensi thermal sebesar $61,99 \%$.

Penggunaan bahan non-kayu berselulosa tinggi sebagai bahan baku alternatif pembuatan pulp merupakan salah satu upaya untuk mengatasi masalah eksploitasi kayu secara berlebihan. Limbah padat hasil pertanian berpotensi sebagai sumber serat selulosa, diantaranya tandan kosong kelapa sawit (TKKS) dan pelepah pisang. TKKS mengandung selulosa 45,95\% dan lignin 16,49\% [7], sedangkan kadar selulosa pada serat pelepah pisang sebesar $63-64 \%$ dan lignin 5\%. Kandungan lignin yang relatif rendah menjadikan proses pembuatan pulp membutuhkan bahan pemasak yang relatif sedikit dan waktu relatif lebih singkat sehingga dapat memberikan keuntungan ekonomis [8].

Berdasarkan tinjauan tersebut, maka dilakukan penelitian lebih lanjut mengenai pengeringan pulp yaitu dengan dilakukan perancangan alat pengering tipe tray untuk pengeringan pulp berbahan baku campuran tandan kosong kelapa sawit (TKKS) dan pelepah pisang. Tujuan penelitian ini adalah merancang suatu unit prototype alat pengering tipe tray untuk pengeringan pulp dari campuran tandan kosong kelapa sawit (TKKS) dan pelepah pisang, menentukan kinerja dari alat pengering tipe tray ditinjau dari efisiensi thermal, dan mendapatkan pulp yang memenuhi standar kadar air berdasarkan Standar Nasional Indonesia No. 6106-2006.

\section{METODE PENELITIAN}

Penelitian menggunakan metode rancang bangun dan eksperimen. Metode rancang bangun dilakukan untuk perancangan alat pengering tipe tray pada pengeringan pulp. Metode eksperimen dilakukan untuk pengujian kinerja pengering tipe tray dalam menentukan kinerja alat ditinjau dari efisiensi thermal.

\subsection{Pendekatan Desain Fungsional}

Pada pendekatan ini rancang bangun alat pengering tipe tray pada proses pembuatan pulp terdiri dari beberapa komponen dengan fungsinya masing-masing, diantaranya adalah elemen pemanas (heater), digunakan untuk memanaskan udara sehingga kelembaban relatif udara pengering turun, dimana kalor yang dihasilkan dibawa oleh aliran udara yang melewati elemen pemanas sehingga proses penguapan air dari dalam bahan dapat berlangsung. Kipas ( $f a n$ ), digunakan untuk menghembuskan udara panas dan mengatur sirkulasi udara dalam alat pengering. Thermocouple atau sensor suhu adalah instrumen yang digunakan untuk mendeteksi dan mengukur suhu. Sensor suhu yang digunakan yaitu thermocoupel tipe K. Thermocontrol atau kontrol suhu adalah proses dimana perubahan suhu ruang dapat diukur atau terdeteksi dan bagian dari energi panas yang ke dalam atau keluar dari ruang disesuaikan untuk mencapai suhu rata-rata yang diinginkan. Hygrometer digital, digunakan untuk menentukan kelembaban atmosfer yang dapat menunjukkan kelembaban relatif (persentase kelembaban di udara), kelembaban mutlak (jumlah kelembaban) atau keduanya. Anemometer, digunakan untuk mengukur kecepatan udara atau kecepatan gas. Cerobong, berfungsi sebagai tempat keluarnya uap air pada proses pengeringan. Rak, berfungsi sebagai tempat produk yang akan dikeringkan.

\subsection{Pendekatan Desain Struktural}

\section{Keterangan :}

1. Control Panel

2. Thermocontrol Digester

3. Sensor Pengaduk

4. Thermocontrol Pengering Tipe Tray

5. Cerobong Udara Output
6. Rak Pengering

7. Strip Heater

8. Thermocouple Pengering Tipe Tray

9. Roda

10. Fan 

11. Press
12. Valve Output
13. Band Heater
14. Thermocouple Digester
15. Penutup Digester
16. Safety Valve

17. Pressure Gauge

18. Impeller

19. Kerangka Alat

20. Motor Pengaduk

21. Speed Controlle

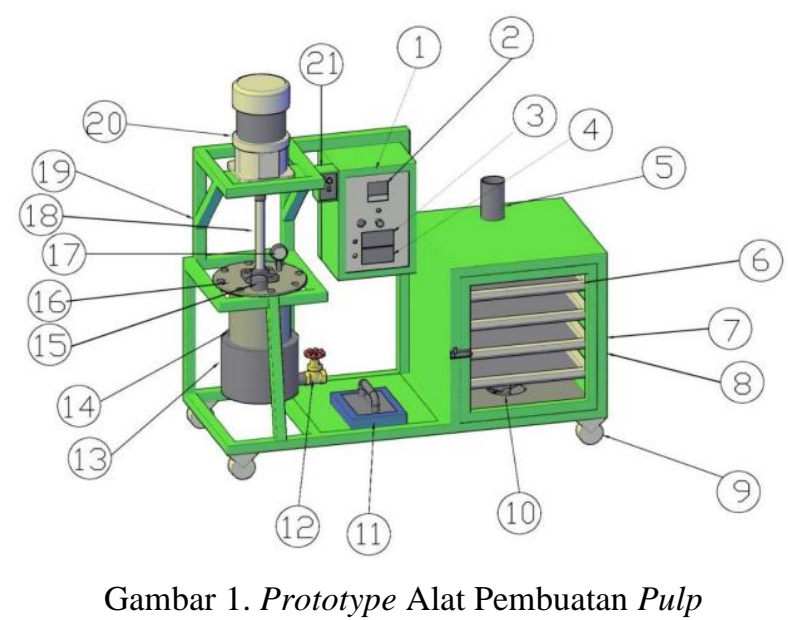

\subsection{Pertimbangan Percobaan}

\subsubsection{Waktu dan Tempat}

Pelaksanaan perancangan alat dilakukan pada bulan April 2021 s.d. Juli 2021, sedangkan penelitian pengeringan pulp dilakukan pada bulan Juli 2021 di Laboratorium Pilot Plant, Mikrobiologi, dan Satuan Operasi Jurusan Teknik Kimia Politeknik Negeri Sriwijaya.

\subsubsection{Alat dan Bahan}

Alat dan bahan yang digunakan pada proses perancangan pengering tipe tray, diantaranya adalah 1 buah gerinda, 1 buah mesin las, 1 buah obeng, tang dan palu, 1 buah meteran, 1 buah bor, 2 buah gergaji besi, 1 buah pensil, 1 buah penggaris, 1 buah gunting. Adapun bahan untuk perancangan pengering tipe tray, diantaranya adalah 2 keping plat stainless steel $0,33 \mathrm{~mm}, 2$ buah heater, 1 buah sensor thermocoupel tipe $\mathrm{k}$, 1 buah thermocontrol (setpoint), 1 buah SSR (solid state relay), 1 buah fan, 1 buah hygrometer digital, 1 buah anemometer, 4 buah rak ukuran $32 \mathrm{~cm}$ x $34 \mathrm{~cm} \times 1 \mathrm{~cm}$.

Alat dan bahan yang digunakan pada proses penelitian pengeringan, diantaranya adalah 1 unit seperangkat alat pengering tipe tray, 100 gram pulp dari TKKS dan pelepah pisang, 2 buah gelas kimia $250 \mathrm{~mL}, 1 \mathrm{buah}$ labu takar 1L, 1 buah neraca analitik, 1 buah cawan porselin, 1 buah oven, 1 buah stopwatch, 1 buah alat press, 2.000 gram tandan kosong kelapa sawit, 2.000 gram pelepah pisang, 4.000 gram $\mathrm{NaOH}, 20.000 \mathrm{ml}$ aquadest.

\subsubsection{Perlakuan dan Analisis Statistik Sederhana}

Untuk pengujian kinerja alat pengering tipe tray, variabel bebas pada penelitian ini adalah temperatur pengeringan yaitu $60^{\circ} \mathrm{C}, 70^{\circ} \mathrm{C}$, dan $80^{\circ} \mathrm{C}$ dan waktu pengeringan yaitu 30 menit, 60 menit, 90 menit, 120 menit, 150 menit, 180 menit, dan 210 menit. Parameter kontrol pada penelitian ini adalah bahan baku yaitu pulp berbasis campuran tandan kosong kelapa sawit (TKKS) dan pelepah pisang, massa pulp sebanyak 100 gram, perbandingan tandan kosong kelapa sawit (TKKS) : pelepah pisang yaitu 1:2, temperatur pemasakan $120^{\circ} \mathrm{C}$, waktu pemasakan 120 menit, dan konsentrasi pelarut $\mathrm{NaOH}$ yaitu $9 \%$. Variabel terikat dalam penelitian ini adalah kadar air pulp.

\subsubsection{Prosedur Penelitian}

a. Perakitan Alat Pengering Tipe Tray

Alat dan bahan dipersiapkan untuk perakitan alat pengering tipe tray. Kerangka alat pengering dibuat dari material plat stainless steel 0,33 mm dengan ukuran $40 \mathrm{~cm}$ x $39,5 \mathrm{~cm}$ x $45 \mathrm{~cm}$ serta dibuat ruang pengering dengan ukuran $34,5 \mathrm{~cm} \times 35 \mathrm{~cm} \times 39,5 \mathrm{~cm}$ dan pondasi tiang penyangga alat pengering. Fan 
dipasang pada bagian dasar pengering dan dihubungkan dengan elemen pemanas (heater) yang dipasang pada bagian kanan, kiri, dan dasar pengering untuk menghasilkan udara panas. Rak pengeringan ukuran 32 $\mathrm{cm}$ x $34 \mathrm{~cm} \times 1 \mathrm{~cm}$ dipasang pada kerangka alat pengering sebanyak 4 rak. Pintu bukaan dibuat untuk umpan masuk. Cerobong dibuat di bagian atas alat pengering untuk udara keluar. Sensor thermocouple tipe $\mathrm{K}$, hygrometer digital serta control panel yang terdiri dari tombol on/off ,display (pengatur temperatur), dan pengatur kecepatan fan dipasang.

b. Preparasi Sampel Pulp (Pembuatan Pulp)

Sampel tandan kosong kelapa sawit (TKKS) dan pelepah pisang dibersihkan dan dipotong menjadi ukuran kecil, kemudian dikeringkan dibawah sinar matahari. Sampel kering dihaluskan menggunakan crusher, hingga didapatkan hasil berbentuk serbuk. Serbuk TKKS dan pelepah pisang ditimbang sebanyak 400 gram dengan perbandingan 1:2. Padatan Natrium Hidroksida $(\mathrm{NaOH})$ ditimbang sebanyak 400 gram, kemudian dilarutkan dalam $4.000 \mathrm{~mL}$ aquadest. Larutan pemasak $\mathrm{NaOH}$ dimasukkan ke dalam wadah yang berisikan serbuk TKKS dan pelepah pisang. Campuran sampel tersebut dimasak menggunakan digester dengan temperatur $120^{\circ} \mathrm{C}$ selama 120 menit. Setelah proses pemasakan, hasil pemasakan didinginkan, lalu disaring dan dicuci untuk dipisahkan sisa hasil pemasakan yang berupa lindi hitam (black liquor) dan raw pulp.

c. Pengujian Alat Pengering Tipe Tray (Pengeringan Pulp)

Pulp ditimbang sebanyak 100 gram sebagai berat awal pulp. Pulp dicetak menggunakan alat press dan diukur temperatur awal pulp sebelum proses pengeringan. Fan dinyalakan dan diatur kecepatan fan. Pulp dimasukkan ke dalam rak pengeringan. Heater dinyalakan dengan menekan tombol $\mathrm{ON}$ dan temperatur diatur berkisar $60^{\circ} \mathrm{C}, 70^{\circ} \mathrm{C}$, dan $80^{\circ} \mathrm{C}$ untuk proses pengeringan. Temperatur bola kering, temperatur bola basah, laju udara dan kelembaban input diukur sebelum proses pengeringan dan proses pengeringan yang terjadi diamati. Setelah pengeringan 30 menit, 60 menit, 90 menit, 120 menit, 150 menit, 180 menit, dan 210 menit temperatur bola kering, temperatur bola basah, laju udara dan kelembaban output diukur. Tombol OFF pada heater ditekan setelah proses pengeringan selesai. Pulp kering dikeluarkan dari ruang pengering, kemudian pulp ditimbang sebagai berat akhir dan temperatur pulp diukur setelah proses pengeringan. Penyaringan juga dilakukan untuk memisahkan kotoran pada pulp hasil pemasakan.

d. Pengujian Kadar Air (Metode Oven SNI No. 08-7070-2005)

Cawan kosong dan tutupnya dipanaskan dalam oven pada temperatur $105^{\circ} \mathrm{C} \pm 3^{\circ} \mathrm{C}$ selama 1 jam kemudian cawan kosong dan tutupnya didinginkan dalam desikator selama 10 menit. Cawan kosong ditimbang sebagai massa cawan awal. Sampel ditimbang sebanyak 2 gram $\pm 0,1$ gram dan dimasukkan ke dalam cawan. Cawan yang berisi sampel pulp dipanaskan dalam oven pada temperatur $105^{\circ} \mathrm{C} \pm 3^{\circ} \mathrm{C}$ selama 3 jam. Sampel pulp beserta cawan yang telah dipanaskan dikeluarkan dari oven dan didinginkan di dalam desikator selama 15 menit. Cawan dan sampel ditimbang kembali setelah dikeringkan. Pemanasan dan penimbangan diulangi sampai diperoleh berat tetap.

\section{HASIL DAN PEMBAHASAN}

\subsection{Hasil Prototype Alat Pengering Tipe Tray}

Perancangan prototype alat pengering tipe tray memiliki kapasitas maksimal 41,989 kg dengan ukuran 39,5 $\mathrm{cm}$ x $45 \mathrm{~cm}$ x $39 \mathrm{~cm}$ berbahan stainlees steel. Pengering memiliki tray sebanyak 4 tingkat dengan jarak 7,5 cm pada setiap tray. Energi panas dihasilkan dari strip heater yang berjumlah 2 buah dengan daya 100 watt. Untuk meningkatkan laju udara pengering dipasang 1 buah kipas (fan) dengan daya 30,8 watt, diletakkan pada sisi bawah pengering tipe tray sehingga didapatkan udara panas yang mengalir ke alat pengering dan akan berkontak langsung dengan pulp.

\subsection{Pengaruh Temperatur Pengeringan dan Waktu Pengeringan terhadap Kadar Air Pulp}

Kadar air merupakan salah satu sifat kimia dari suatu bahan yang menunjukkan banyaknya air yang terkandung di dalam bahan tersebut. Prinsip pengukuran kadar air pada pulp adalah dengan menguapkan air yang terkandung pada pulp dengan cara pemanasan, kemudian bahan ditimbang hingga berat konstan [9]. Proses pengeringan ini bertujuan untuk menurunkan kadar air pulp hingga mencapai $\leq 12 \%$ berdasarkan Standar Nasional Indonesia No. 6106-2006. Hasil analisis kadar air yang telah dilakukan dengan menggunakan metode oven berdasarkan Standar Nasional Indonesia No. 08-7070-2005 didapatkan nilai kadar air rata-rata awal dalam pulp sebesar $79,7 \%$.

Gambar 2 menunjukkan kadar air pada pulp selama pengeringan 210 menit pada tray 1, tray 2, tray 3, dan tray 4 pada pengering tipe tray. Pengeringan pada tray 1 dapat memenuhi standar kadar air SNI No. 6106-2006 dengan kadar air maksimal $12 \%$ yaitu pada temperatur pengeringan $60^{\circ} \mathrm{C}$ dengan waktu pengeringan 210 menit 
menghasilkan kadar air sebesar 8,3\% dari kadar air awal 80\%, pada temperatur pengeringan $70^{\circ} \mathrm{C}$ dengan waktu pengeringan 150 menit menghasilkan kadar air sebesar 10,9\% dari kadar air awal 79,83\% dan pada temperatur pengeringan $80^{\circ} \mathrm{C}$ dengan waktu pengeringan 150 menit menghasilkan kadar air sebesar 7,5\% dari kadar air awal $79,35 \%$. Pengeringan pada tray 2 dapat memenuhi standar kadar air yaitu pada temperatur pengeringan $60^{\circ} \mathrm{C}$ dengan waktu pengeringan 210 menit menghasilkan kadar air sebesar 9,5\%, pada temperatur pengeringan $70^{\circ} \mathrm{C}$ dengan waktu pengeringan 180 menit menghasilkan kadar air sebesar 8,1\%, dan pada temperatur pengeringan $80^{\circ} \mathrm{C}$ dengan waktu pengeringan 150 menit menghasilkan kadar air sebesar 10,1\%. Pengeringan pada tray 3 dan tray 4 belum dapat memenuhi kadar air yang sesuai dengan SNI, sehingga diperlukan waktu pengeringan yang lebih lama lagi.

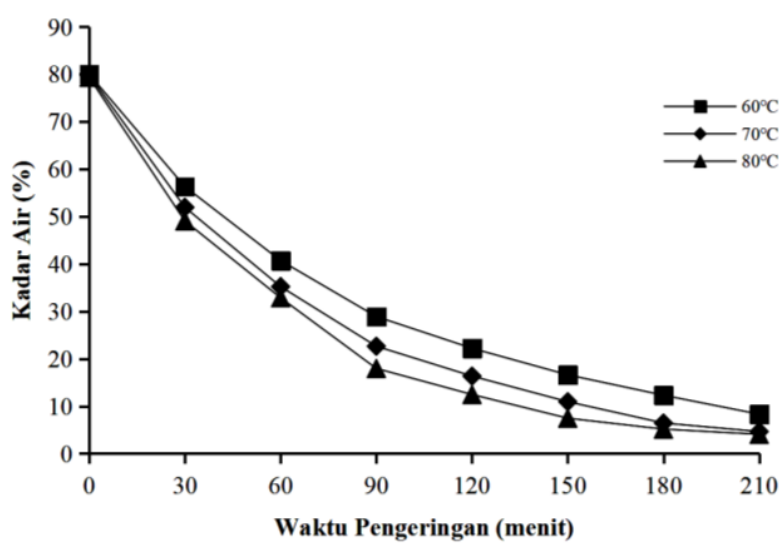

(a)

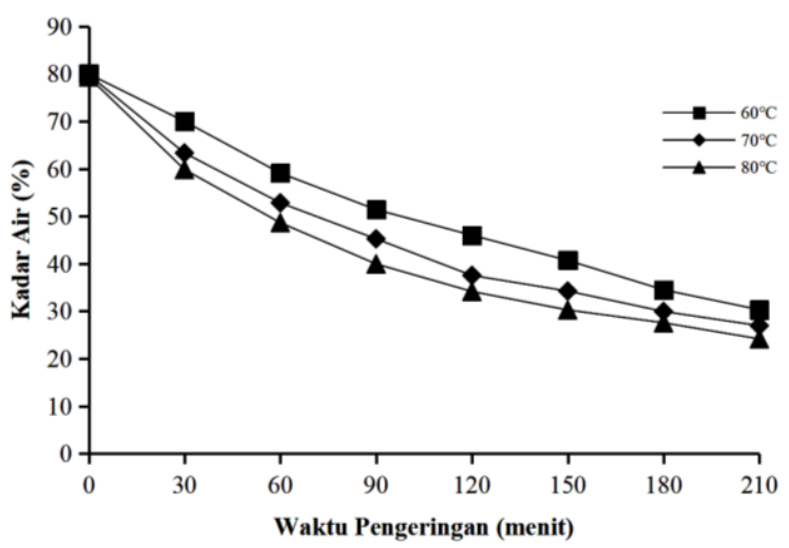

(c)

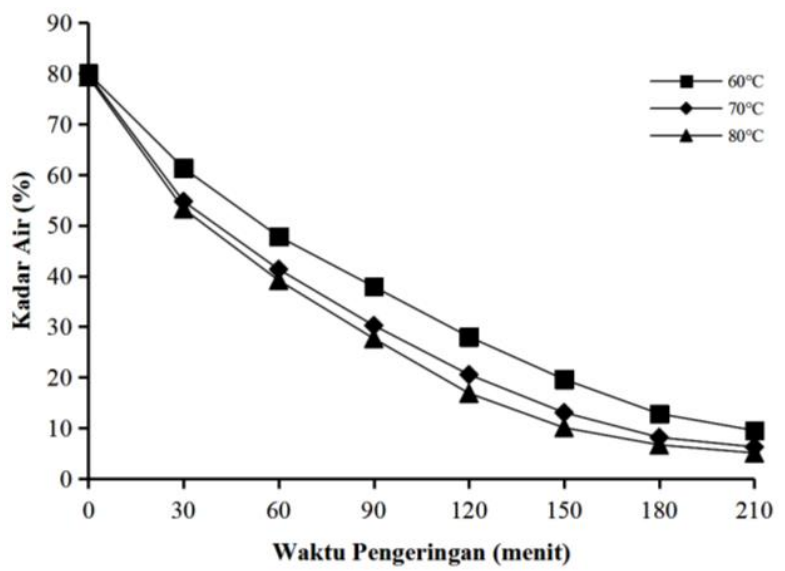

(b)

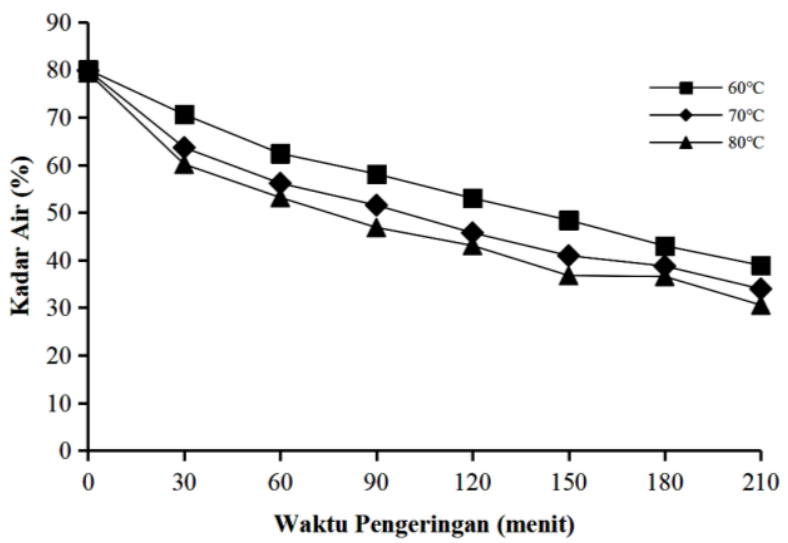

(d)

Gambar 2. (a) Hubungan Temperatur Pengeringan dan Waktu Pengeringan terhadap Kadar Air pada Tray 1, (b) Hubungan Temperatur Pengeringan dan Waktu Pengeringan terhadap Kadar Air pada Tray 2, (c) Hubungan Temperatur Pengeringan dan Waktu Pengeringan terhadap Kadar Air pada Tray 3, (d) Hubungan Temperatur Pengeringan dan Waktu Pengeringan terhadap Kadar Air pada Tray 4

Dalam hal ini, dapat diketahui bahwa semakin tinggi temperatur pengeringan, maka semakin rendah kadar air dalam pulp yang dihasilkan. Hal ini dikarenakan kenaikan temperatur akan menyebabkan molekul air yang menguap sebakin banyak sehingga kadar air sisa yang diperoleh semakin rendah. Semakin besar perbedaan temperatur udara pengering dengan pulp yang dikeringkan, maka semakin besar pula kecepatan pindah panas ke dalam pulp, oleh karena itu penguapan air dari pulp akan semakin cepat. Dimana kemampuan bahan untuk melepaskan air dari permukaannya akan semakin besar dengan meningkatnya temperatur udara pengering yang digunakan [10].

Penurunan kadar air yang terjadi pada pulp juga sangat dipengaruhi oleh waktu pengeringan yang dilakukan. Waktu pengeringan yang lama menyebabkan kontak antar pulp dan udara panas semakin lama, mengakibatkan kadar air pada pulp akan menguap semakin besar sehingga semakin besar pula penurunan kadar air yang terjadi pada pulp [10]. Namun, waktu pengeringan yang terlalu lama tidak menjamin pengeringan akan 
semakin baik. Hal ini dikarenakan terdapat waktu pengeringan optimum yaitu lama pengeringan sampai bahan baku mencapai kadar air sesuai Standar Nasional Indonesia.

Perbedaan hasil kadar air pulp setelah proses pengeringan pada setiap tray menunjukkan proses pengeringan yang terjadi tidak merata. Hal ini disebabkan oleh temperatur dan sirkulasi udara pengering yang tidak merata pada ruang pengering. Letak fan dimana masuknya udara pengering berada pada bagian bawah tray 1 yang menyebabkan udara pengering akan berkontak langsung dengan pulp sehingga ketika udara pengering bersirkulasi dan secara langsung berkontak dengan pulp pada tray 1, maka tingkat kejenuhan udara dan temperatur udara pengeringan pada tray lainnya untuk mengeringkan pulp telah berubah.

Kondisi optimum pengeringan pulp sehingga didapatkan kadar air pulp yang memenuhi SNI No. 61062006 adalah pada temperatur pengeringan $80^{\circ} \mathrm{C}$ selama waktu pengeringan 180 menit pada tray 1 pengering tipe tray yaitu sebesar $7,5 \%$.

\subsection{Pengaruh Temperatur Pengeringan terhadap Laju Perpindahan Panas Konveksi dan Laju Perpindahan Panas Konduks}

Pada pengeringan terjadi proses perpindahan panas meliputi perpindahan panas secara konveksi dan konduksi. Perpindahan panas konveksi terjadi karena fluida (udara panas) mengalami kontak secara langsung dengan bahan yang dikeringkan yaitu pulp (udara dingin) dan terjadi aliran dari bagian bertemperatur tinggi ke bagian bertemperatur rendah.

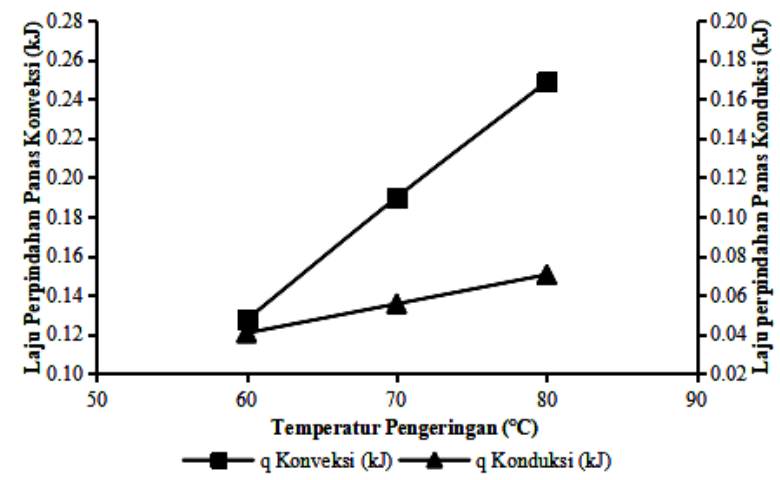

(a)

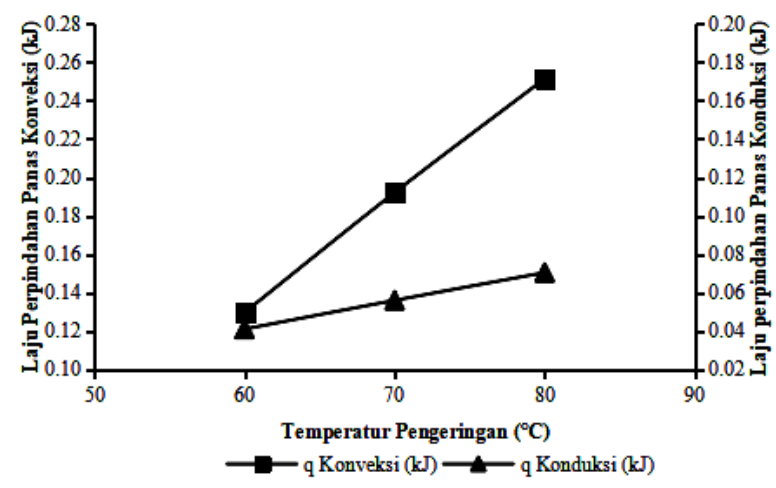

(c)

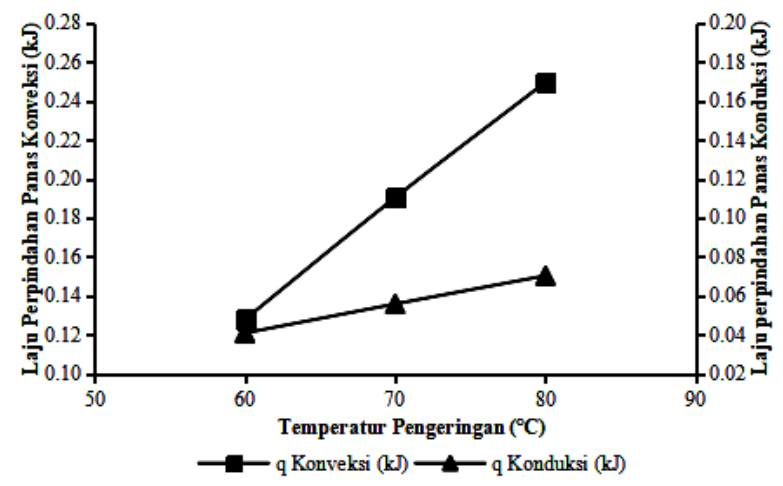

(b)

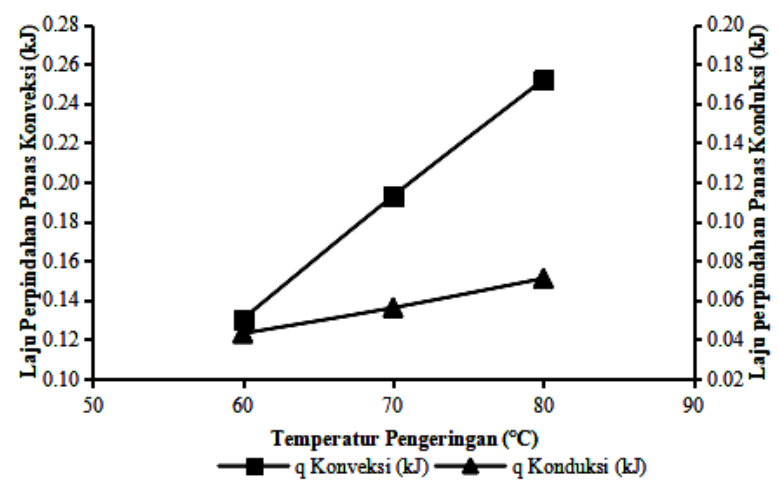

(d)

Gambar 3. (a) Hubungan Temperatur Pengeringan terhadap Laju Perpindahan Panas Konveksi dan Laju Perpindahan Panas Konduksi pada Tray 1, (b) Hubungan Temperatur Pengeringan terhadap Laju Perpindahan Panas Konveksi dan Laju Perpindahan Panas Konduksi pada Tray 2, (c) Hubungan Temperatur Pengeringan terhadap Laju Perpindahan Panas Konveksi dan Laju Perpindahan Panas Konduksi pada Tray 3, (d) Hubungan Temperatur Pengeringan terhadap Laju Perpindahan Panas Konveksi dan Laju Perpindahan Panas Konduksi pada Tray 4

Gambar 3 menjelaskan hubungan temperatur pengeringan terhadap laju perpindahan panas konveksi dan laju perpindahan konduksi pada tray 1, tray 2, tray 3, dan tray 4 pengering tipe tray. Laju perpindahan panas konveksi rata-rata pada temperatur pengeringan $60^{\circ} \mathrm{C}, 70^{\circ} \mathrm{C}$, dan $80^{\circ} \mathrm{C}$ tertinggi yaitu pada tray 4 berturut-turut 
sebesar $0,1304 \mathrm{~kJ} ; 0,1929 \mathrm{~kJ} ; 0,2521 \mathrm{~kJ}$; sedangkan laju perpindahan panas konveksi rata-rata terendah yaitu pada tray 1 berturut-turut sebesar $0,1273 \mathrm{~kJ} ; 0,1898 \mathrm{~kJ} ; 0,2489 \mathrm{~kJ}$.

Semakin tinggi temperatur pengeringan maka laju perpindahan panas konveksi yang terjadi semakin besar. Hal ini menunjukkan bahwa, terjadi kontak langsung antar pulp dan media udara panas pengering, dengan tingginya temperatur udara pengering maka air yang terdapat pada permukaan pulp akan teruapkan lebih banyak dan terjadi penurunan dari kandungan air pada pulp. Nilai laju perpindahan panas konveksi yang tinggi menjadikan proses perpindahan panas yang terjadi juga optimal, sehingga dengan adanya perbedaan temperatur, air pada pulp akan banyak yang menguap karena proses perpindahan panas yang terjadi berjalan secara optimal.

Laju perpindahan panas konveksi bergantung pada perubahan temperatur, luas permukaan, dan koefisien perpindahan panas konveksi (hc). Semakin tinggi temperatur udara pengering dan temperatur pelat pengering mengakibatkan semakin besar laju perpindahan panas konveksi, hal ini dikarenakan panas pada ruang pengering terdistribusi lebih merata seiring dengan kenaikan temperatur [11]. Naik turunnya nilai laju perpindahan panas konveksi juga dipengaruhi oleh perubahan angka Reynolds [12]. Perpindahan panas konveksi yang terjadi pada pengering memiliki arah aliran laminar karena memiliki bilangan reynold sebesar 0,0244. Arah aliran dikatakan laminar bila memiliki nilai bilangan Reynolds yang kecil $(<2100)$. Aliran laminer bersifat steady yaitu aliran tetap dimana kecepatan aliran tidak berubah menurut waktu.

Perpindahan panas konduksi terjadi ketika panas dari dinding pelat (partikel yang berenergi lebih tinggi) masuk ke dalam pulp yang dikeringkan (partikel yang berenergi lebih rendah) sebagai akibat dari interaksi antar partikel tersebut. Laju perpindahan panas konduksi rata-rata pada temperatur pengeringan $60^{\circ} \mathrm{C}, 70^{\circ} \mathrm{C}$, dan $80^{\circ} \mathrm{C}$ tertinggi yaitu pada tray 4 berturut-turut sebesar $0,0430 \mathrm{~kJ} ; 0,0561 \mathrm{~kJ} ; 0,0710 \mathrm{~kJ}$ sedangkan laju perpindahan panas konduksi rata-rata terendah yaitu pada tray 1 berturut-turut sebesar $0,0405 \mathrm{~kJ} ; 0,0554 \mathrm{~kJ} ; 0,0703 \mathrm{~kJ}$.

Kenaikan laju perpindahan panas konduksi rata-rata disebabkan pada setiap lapisan pulp terjadi kontak langsung antar pulp dan media udara panas di sekitar dinding pelat pengering sehingga terjadi peningkatan laju pindah panas konduksi yang tinggi. Kecepatan udara dan viskositas mempengaruhi dari gerakan partikel udara, sehingga kontak antara udara dengan pulp akan merata. Nilai dari konduktivitas thermal dan specific heat akan mempengaruhi jumal panas yang diserap oleh udara, sehingga laju perpindahan panas cenderung meningkat.

\subsection{Pengaruh Laju Perpindahan Panas Konveksi dan Laju Perpindahan Panas Konduksi terhadap Efisiensi Thermal Alat}

Proses perpindahahan panas yang terjadi merupakan variabel utama dalam menentukan efisiensi dan unjuk kerja alat. Kinerja dari alat pengering tipe tray dapat ditinjau salah satunya dari nilai efisiensi thermal, dengan mengetahui efisiensi thermal dari suatu alat maka dapat diketahui tingkat kinerja dari ruang pengering dalam proses pengeringan pulp.

Efisiensi thermal tertinggi tercapai pada temperatur pengeringan $60^{\circ} \mathrm{C}$ dalam waktu 120 menit pada tray 3 yaitu efisiensi thermal sebesar $93,485 \%$, pada kondisi ini didapatkan nilai laju perpindahan panas konveksi sebesar $0,1283 \mathrm{~kJ}$, sedangkan efisiensi thermal terendah tercapai pada temperatur pengeringan $80^{\circ} \mathrm{C}$ dalam waktu pengeringan 60 menit pada tray 1 yaitu sebesar 76,136\%, pada kondisi ini didapatkan nilai laju perpindahan panas konveksi sebesar $0,2483 \mathrm{~kJ}$.

Pada Gambar 4. dapat diketahui bahwa peningkatan efisiensi thermal alat diakibatkan oleh penurunan laju perpindahan panas konveksi. Hal ini disebabkan karena udara panas yang besar berasal dari konversi listrik terhadap udara yang dipanaskan oleh heater dan dihembuskan melalui fan. Namun, kenaikan temperatur ruang yang disebabkan oleh besarnya udara panas ini menyebabkan efisiensi thermal yang dihasilkan cenderung semakin kecil. Hal ini dikarenakan kenaikan temperatur pada ruang pengering akan mengakibatkan heat loss yang terjadi semakin besar [6], sehingga menyebabkan efisiensi thermal semakin rendah begitu pula sebaliknya. Luas permukaan cerobong udara keluar yang besar berpotensi menyebabkan banyak udara panas keluar melalui cerobong sehingga nilai heat loss mengalami kenaikan.

Sama halnya seperti laju perpindahan panas konveksi, efisiensi thermal juga dipengaruhi oleh laju perpindahan panas konduksi, efisiensi thermal tertinggi yaitu sebesar $93,485 \%$, pada kondisi ini didapatkan nilai laju perpindahan panas konduksi sebesar $0,0414 \mathrm{~kJ}$, sedangkan efisiensi thermal terendah yaitu sebesar $76,136 \%$, pada kondisi ini didapatkan nilai laju perpindahan panas konduksi sebesar $0,0728 \mathrm{~kJ}$.

Peningkatan efisiensi thermal alat dipengaruhi oleh peningkatan laju perpindahan panas konduksi. Hal ini dikarenakan besarnya energi dari udara panas yang dapat menguapkan air yang ada di bahan pulp. Namun, kenaikan temperatur ruang yang disebabkan oleh besarnya udara panas ini menyebabkan efisiensi thermal yang dihasilkan cenderung semakin kecil. Nilai heat loss pada proses pengeringan pulp dipengaruhi oleh besarnya serapan energi panas melalui dinding-dinding tempat mengalirnya udara panas untuk proses pengeringan [6]. Semakin besar terserapnya energi panas melalui dinding-dinding tempat mengalirnya udara panas untuk proses pengeringan semakin besar kehilangan panas melalui dinding-dinding pengering, dikarenakan tidak 
digunakannya isolasi secara menyeluruh pada dinding-dinding ruang pengering sehingga menyebabkan banyak kehilangan panas.

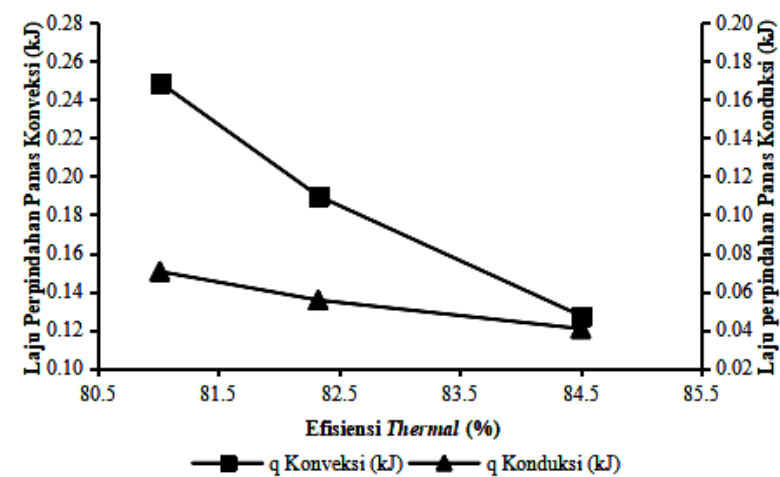

(a)

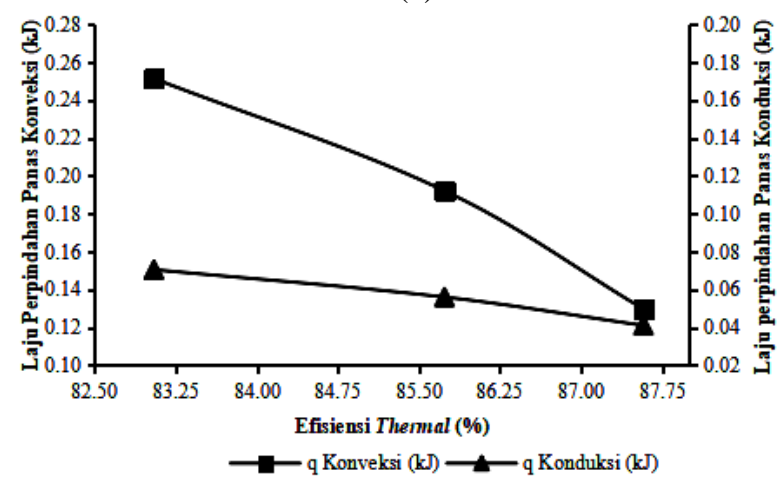

(c)

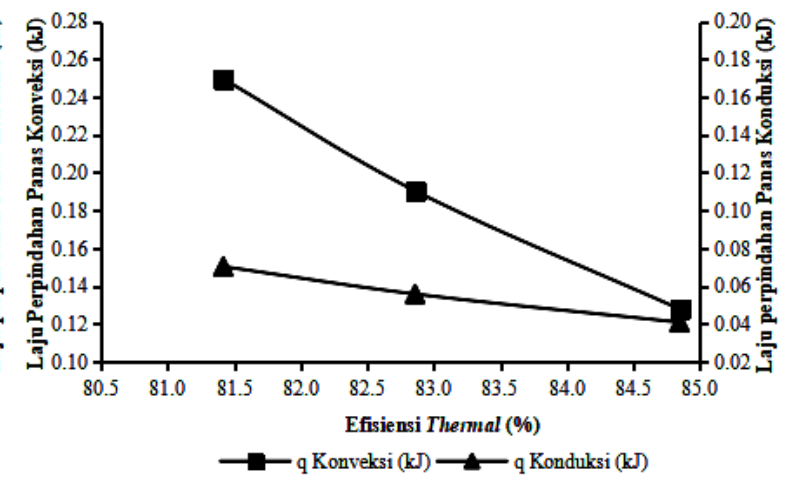

(b)

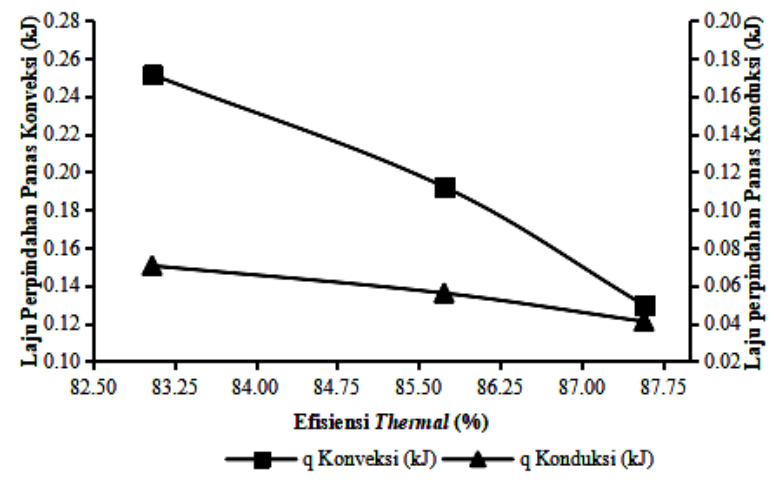

(d)

Gambar 4. (a) Hubungan Laju Perpindahan Panas Konveksi dan Laju Perpindahan Panas Konduksi terhadap Efisiensi Thermal pada Tray 1, (b) Hubungan Laju Perpindahan Panas Konveksi dan Laju Perpindahan Panas Konduksi terhadap Efisiensi Thermal pada Tray 2, (c) Hubungan Laju Perpindahan Panas Konveksi dan Laju Perpindahan Panas Konduksi terhadap Efisiensi Thermal pada Tray 3, (d) Hubungan Laju Perpindahan Panas Konveksi dan Laju Perpindahan Panas Konduksi terhadap Efisiensi Thermal pada Tray 4

\section{KESIMPULAN}

Perancangan prototipe alat pengering tipe tray memiliki ukuran $39,5 \mathrm{~cm}$ x $45 \mathrm{~cm}$ x $39 \mathrm{~cm}$ berbahan stainlees steel dengan jumlah tray 4 tingkat, dengan menggunakan energi panas yang dihasilkan dari strip heater, dan memiliki sistem konveksi paksaan (forced convection). Efisiensi thermal tertinggi pada pengering tipe tray yang didapat yaitu pada temperatur pengeringan $60^{\circ} \mathrm{C}$ dengan waktu pengeringan 120 menit pada tray 3 yaitu sebesar 93,485\%. Pulp yang dihasilkan dari pengering tipe tray telah memenuhi standar kadar air yang sesuai dengan Standar Nasional Indonesia No. 6106-2006, yaitu pada temperatur pengeringan $80^{\circ} \mathrm{C}$ dengan waktu pengeringan 150 menit pada tray 1 didapatkan kadar air 7,5\%.

\section{DAFTAR PUSTAKA}

[1] E. B. Prayekti, A. Amalia, I. Afriyanti, and T. Santoso, "Pengujian Tingkat Kelembaban Lembaran Kertas Setelah Melalui Tahap Pengeringan,” Jurnal Saintifika, vol. 18, no. 1, 2016.

[2] F. Wijayanti and S. Hariani, "Pengaruh Pengeringan Biji Kopi dengan Metode Rumah Kaca dan Penyinaran Sinar Matahari Terhadap Kadar Air Biji Kopi Robusta (Coffea Robusta)." Prosiding Seminar Nasional Sains Dan Teknologi, vol. 2, no.1, 2019.

[3] Kementrian Perindustrian Republik Indonesia. "Pedoman Pemetaan Teknologi Untuk Industri Pulp dan Kertas,” Kementrian Perindustrian Republik Indonesia, Jakarta, 2011.

[4] G. Prayitno and S. S. Utami, "Jenis Alat dan Lama Pengeringan Terhadap Kualitas Mutu Pada Pembuatan Teh Cascara," Prosiding Seminar Nasional Pengabdian Kepada Masyarakat dan Penelitian, 
pp. 321-324, 2019.

[5] I. Purnamasari, A. Meidinariasty, and R. N. Hadi, "Prototype Alat Pengering Tray Dryer Ditinjau dari Pengaruh Temperatur dan Waktu Terhadap Proses Pengeringan Mie Kering," Jurnal Kinetika, vol. 10, no. 3, pp. 25-28, 2019.

[6] N. A. Yuliasdini, S. U. Putri, T. A. Makaminan, and S. Yuliati, "Efisiensi Termal Alat Pengering Tipe Tray Dryer untuk Pengeringan Silika Gel Berbasis Ampas Tebu," Prosiding Seminar Mahasiswa Teknik Kimia, vol. 1, no. 1, pp. 29-33, 2020.

[7] J. Warsito, S. M. Sabang, and K. Mustapa, "Pembuatan Pupuk Organik dari Limbah Tandan Kosong Kelapa Sawit,” Jurnal Akademika Kimia, vol. 5, no. 1, pp. 8-15, 2016.

[8] N. S. Hartati, "Prospek Penggunaan Kayu Rendah Lignin Hasil Teknologi DNA untuk Proses Pulping Yang Efisien Dan Ramah Lingkungan,” Jurnal Ecolab, vol. 10, no. 1, pp. 29-40, 2016.

[9] L. Reringga, Mursalin, and I. Rahmayani, "Kajian Proses Pengeringan Cabai Merah Menggunakan Vaccum Dryer dengan Penambahan Maltodekstrin dan Aplikasinya dalam Pembuatan Abon Cabai," Prosiding Semirata BKS-PTN Wilayah Barat Bidang Ilmu Pertanian, vol. 1, no. 1, pp. 1395-1414, 2019.

[10] S. Amin and M. Rais, "Laju Pindah Panas dan Massa Pada Proses Pengeringan Gabah Menggunakan Alat Pengering Tipe Bak (Batch Dryer)," Jurnal Pendidikan Teknologi Pertanian, vol. 4, pp. 87-104, 2020.

[11] M. Hatta, A. Syuhada, and Z. Fuadi, "Sistim Pengeringan Ikan dengan Metode Hybrid," Jurnal Polimesin, vol. 17, no. 1, pp. 9-18, 2019.

[12] S. Yuliati, "Unjuk Kerja Rotary Dryer pada Proses Pengeringan Biji Kopi," Jurnal Kinetika, vol. 9, no. 3, pp. 38-42, 2018. 